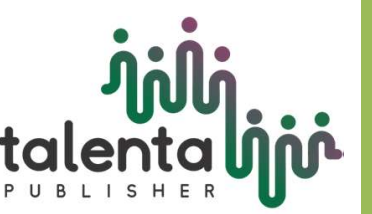

\title{
Growth Response of Two Pepper (Piper nigrum L.) Stem Cuttings on Application of IBA (Indole Butyric Acid) and NAA (Naphthalene Acetic Acid)
}

\section{Rizky Wulanndari, Yaya Hasanah, and Meiriani}

Department of Agrotechnology, Faculty of Agriculture, Universitas Sumatera Utara, Indonesia

\begin{abstract}
Using fruit branch for pepper shrub propagation is one of alternatives for an efficient pepper multiplication which usually uses underlayer cuttings. This research is aimed at finding the growth response of two pepper (Piper nigrum L.) cuttings to the administration of IBA (Indole Butyric Acid) and NAA (Naphthalene Acetic Acid). This research was conducted at the greenhouse of the Faculty of Agriculture, University of Sumatera Utara, Medan ( $\pm 32 \mathrm{~m}$ above sea level), from April to August 2017 using a factorial randomized block design with 2 factors, pepper branch cuttings (primary branch cuttings and secondary branch cuttings) and the administration of IBA and NAA $(0+0$ ppm, $2500+0 \mathrm{ppm}, 0+2500 \mathrm{ppm}, 1500+1000 \mathrm{ppm}$, and $1000+1500 \mathrm{ppm})$. The results show that the emerging shoot rate in the secondary branch cuttings was significantly faster than in the primary branch cuttings, but the volume of root in the primary branch cuttings is significantly larger than in the secondary branch cuttings. There was no significant difference in the administration of IBA and NAA on all observed variables. The highest interaction of shoot length was found in the primary branch cuttings with the administration of IBA $1500 \mathrm{ppm}+$ NAA $1000 \mathrm{ppm}$ and the highest percentage of root and root volume was found in the primary branch cuttings with the administration of IBA 2500 $\mathrm{ppm}+\mathrm{NAA} 0 \mathrm{ppm}$.
\end{abstract}

Keywords: Indole Butyric Acid, Naphthalene Acetic Acid, pepper cuttings

Received 24 February 2018 | Revised 28 March 2018 | Accepted 29 March 2018

\section{Introduction}

Pepper (Piper nigrum $\boldsymbol{L}$.) is one of the plantation commodities with a strategic opportunity in a sustainable plantation farming system, both economically and socially. Economically, pepper can serve as one of the main income sources for farmers and a foreign exchange source of nonoil and gas sector for government; meanwhile, socially it is a traditional commodity that has been cultivated for a long time which has provided extensive employment, especially in production center areas [1].

The area of pepper cultivation in Indonesia has increased since the last three years: 162,747 ha in 2014; 163,312 ha in 2015; and 163,986 ha in 2016. The increasing area is in line with the

*Corresponding author at: Department of Agrotechnology, Faculty of Agriculture, Universitas Sumatera Utara,

Jl. Prof A. Sofyan No. 3, Kampus USU, Medan, Indonesia

E-mail address: rizkywulandari@gmail.com 
increasing production in the last three years: 87,445 ton/ha in $2014 ; 88,294$ ton/ha in 2015 ; and 89,302 ton/ha in 2016 [2].

Developing pepper shrub is a potential alternative in improving national pepper competitiveness. Pepper cultivation is made from a vegetative propagation by using cuttings derived from fruit branches [3].

The advantages of pepper shrub cultivation among others are easy climbing, easy planting, high per-unit productivity, early production, and intercropping with other crops [4].

Pepper shrub planting is usually conducted by growing fruit branches on a tread basis by bringing some of the roots of the climbing shoot. This method provides a high success rate, but is less efficient due to a limited quantity of the branches [5].

Therefore, pepper shrub propagation needs to be developed by using fruit branch cuttings that exclude some of the roots of the climbing shoot. Nevertheless, fruit branch cuttings without some of the roots may result in long and unequal root growth; therefore, using growth regulators containing auxin is required to stimulate the root growth. The commonly used growth regulators are IBA and NAA.

Using IBA and NAA is better than IAA because IBA and NAA have more stable chemical characteristics and mobility in plants; have longer effects and remain around the application point without spreading to other parts of the cuttings; do not affect other growth; and, provide fertile roots with ordinary structure. Meanwhile, the IAA may spread to the buds and inhibit the development and the growth of the shoots. Moreover, NAA has a narrow concentration range, whereas IBA has a more flexible range of concentration [6].

Application of NAA at the concentrations of 50,100 and 200 ppm by Maulida et al. [7] on red betel cuttings can increase the number of roots both in the node and the base of cuttings. In another experiment involving Javanese chili conducted by Nilasari [8], it was found that administering $37.5 \mathrm{mg} / \mathrm{L}$ of IBA increased root wet weight and volume.

Based on the above description, the authors are interested in conducting a research using IBA and NAA as the growth regulating substances that can stimulate the growth of roots and shoots with different concentrations on the two pepper shrub (Piper nigrum $\mathbf{L}$.) cuttings.

\section{Materials and Method}

This research was conducted at the greenhouse of Agricultural Faculty of the University of Sumatera Utara, Medan, located \pm 32 meter above sea level, from April to August 2017. The materials used were primary and secondary fruit branches of pepper plant, $15 \mathrm{~cm} \times 20 \mathrm{~cm}$ polybags, top soil, compost, sand, IBA, NAA, aquadest, 95\% alcohol, Dithane M-45, bamboo, clear plastic, and $25 \%$ black paranet. The tools were hoe, ruler, oven, analytical scales, measuring cylinder, magnetic stirrer, hot plate, beaker glass, hand sprayer, gembor (long mouth 
watering kettle), scissors and cutter. This research applied a factorial Randomized Block Design (RBD) with two factors of treatment. The first factor was the plant cutting (B) consisting of 2 levels: $\mathrm{B}_{1}=$ primary fruit branch, $\mathrm{B}_{2}=$ secondary fruit branch; and the second factor was the application of IBA and NAA (K) consisting of 5 levels: $\mathrm{K}_{0}=0$ ppm, $\mathrm{K}_{1}=\mathrm{IBA}(2500 \mathrm{ppm})+$ NAA $(0 \mathrm{ppm}), \mathrm{K}_{2}=\mathrm{IBA}(0 \mathrm{ppm})+\mathrm{NAA}(2500 \mathrm{ppm}), \mathrm{K}_{3}=\mathrm{IBA}(1500 \mathrm{ppm})+\mathrm{NAA}(1000$ ppm), and K4 = IBA $(1000 \mathrm{ppm})+$ NAA $(1500 \mathrm{ppm})$. The data were analyzed using a significant variance analysis followed by a Duncan Multiple Range Test with $\alpha=5 \%$ [9].

The research procedure started from preparation: field preparation, protection preparation, preparation of hoods, preparation of planting media, preparation of cuttings, preparation of IBA and NAA solution; application: administration of IBA and NAA solution, planting, and hood installation; and maintenance including watering, weeding, and pest and disease controls. The parameters observed were emerging shoot age, emerging shoot rate, number of shoots, shoot length, number of leaves, percentage of sprouted cuttings, percentage of rooted cuttings, root volume, crown wet weight, root wet weight, crown dry weight, and root dry weight.

\section{Results and Discussion}

\subsection{Emerging Shoot Age and Rate}

The emerging shoot age and rate on the treatment of administering IBA and NAA can be seen in Table 1 . The finding presented in Table 1 shows the tendency of the secondary branch cuttings to have a more quickly emerging shoot age (16.84 days) which is not significantly different from the primary ones. In the IBA and NAA administration, the emerging shoot age tends to be faster in the administration of IBA $2500 \mathrm{ppm}+$ NAA $0 \mathrm{ppm}\left(\mathrm{K}_{1}\right)$, i.e. 15.67 days, which is not significantly different from $\mathrm{K}_{0}, \mathrm{~K}_{2}, \mathrm{~K}_{3}$ and $\mathrm{K}_{4}$.

Table 1 also shows that the secondary branch cuttings have a faster emerging shoot rate (16.89 days) which is significantly different from the primary ones (19.21 days). In the IBA and NAA administration, the fastest emerging shoot rate was obtained from the administration of IBA $2500 \mathrm{ppm}+$ NAA $0 \mathrm{ppm}\left(\mathrm{K}_{1}\right)$, i.e. 17.13 days, which is not significantly different from $\mathrm{K}_{0}, \mathrm{~K}_{2}$, $\mathrm{K}_{3}$ and $\mathrm{K}_{4}$.

The emerging shoot age and rate are faster on the secondary branch cuttings $\left(\mathrm{B}_{2}\right)$ because the secondary branches are part of younger plants which have active and undifferentiated tissues, and such tissues experience the process of differentiation into shoots more easily. In addition, on the secondary branches, the endogenous auxin is produced in a large quantity which will induce the emergence of shoots. As Fahmi [10] states that auxin is synthesized at the tip of the stem near the shoot meristem, young tissues (e.g. young leaves) and it mainly moves downward the polar. Its activities include stimulation and inhibition of growth, depending on the auxin concentration. 
Table 1. Emerging Shoot Age and Rate on the Treatment of Administering IBA and NAA

\begin{tabular}{|c|c|c|}
\hline Treatment & Emerging Shoot Age & Emerging Shoot Rate \\
\hline & …....................... & ys............................... \\
\hline \multicolumn{3}{|l|}{ Cuttings(branch) } \\
\hline $\mathrm{B}_{1}$ (Primary) & 17.22 & $19.21 \mathrm{a}$ \\
\hline $\mathrm{B}_{2}$ (Secondary) & 16.84 & $16.89 b$ \\
\hline \multicolumn{3}{|c|}{ Application of IBA and NAA (ppm) } \\
\hline $\mathrm{K} 0(0+0)$ & 16.78 & 18.14 \\
\hline $\mathrm{K} 1(2500+0)$ & 15.67 & 17.13 \\
\hline $\mathrm{K} 2(0+2500)$ & 16.67 & 17.68 \\
\hline $\mathrm{K} 3(1500+1000)$ & 18.17 & 17.73 \\
\hline $\mathrm{K} 4(1000+1500)$ & 17.89 & 19.57 \\
\hline
\end{tabular}

Notes: The numbers followed by similar letters in the same row show no significant difference in Duncan Multiple Range Test at $\alpha=5 \%$

\subsection{Percentage of Sprouted Cuttings}

The percentage of sprouted cuttings on the treatment of administering IBA and NAA can be seen in Table 2.

Table 2. Percentage of Sprouted Cuttings on the Treatment of Administering IBA and NAA

\begin{tabular}{|c|c|c|c|c|c|c|}
\hline \multirow[b]{2}{*}{$\begin{array}{l}\text { Cuttings } \\
\text { (Branch) }\end{array}$} & \multicolumn{5}{|c|}{ Application of IBA and NAA (ppm) } & \multirow[b]{2}{*}{ Mean } \\
\hline & $\begin{array}{c}\mathbf{K}_{\mathbf{0}} \\
(0+0) \\
\end{array}$ & $\begin{array}{c}\mathbf{K}_{\mathbf{1}} \\
(2500+0) \\
\end{array}$ & $\begin{array}{c}\mathbf{K}_{\mathbf{2}} \\
(0+2500)\end{array}$ & $\begin{array}{c}\mathbf{K}_{\mathbf{3}} \\
(1500+ \\
1000)\end{array}$ & $\begin{array}{c}\mathbf{K}_{\mathbf{4}} \\
(1000+ \\
1500) \\
\end{array}$ & \\
\hline & & & & & & \\
\hline $\mathrm{B}_{1}$ (Primary) & 40.00 & 66.67 & 46.67 & 53.33 & 26.67 & 46.67 \\
\hline $\mathrm{B}_{2}$ (Secondary) & 46.67 & 40.00 & 40.00 & 26.67 & 33.33 & 37.33 \\
\hline Mean & 43.33 & 53.33 & 43.33 & 40.00 & 30.00 & \\
\hline
\end{tabular}

Table 2 shows that the highest percentage of sprouted cuttings is obtained from the primary fruit branch cuttings $(46.67 \%)$ which is not significantly different from the secondary fruit branch cuttings. In the case of IBA and NAA, the highest percentage of sprouted cuttings is obtained from the administration of ZPT IBA $2500 \mathrm{ppm}+$ NAA $0 \mathrm{ppm}(\mathrm{K} 1)$, i.e. $53.33 \%$, which is not significantly different from K0, K2, K3 and K4.

The highest percentage of sprouted cuttings is obtained from the primary fruit branch. Presumably, this is caused by the availability of nutrient in the primary branch cuttings is more than in the secondary branch cuttings. The availability of nutrient provides sufficient energy for plants to develop, enlarge and elongate the cell which will influence the better growth of plant organs until the end of the research. This is in line with Hartmann et al. [11] arguing that the success rate of cuttings in producing shoots is caused by the availability of sufficient nutrient possessed by the cuttings for their growth and development. 


\subsection{Percentage of Rooted Cuttings}

The percentage of rooted cuttings on the treatment of administering IBA and NAA can be seen in Table 3.

Table 3. Percentage of Rooted Cuttings on the Treatment of Administering IBA and NAA

\begin{tabular}{|c|c|c|c|c|c|c|}
\hline \multirow[b]{2}{*}{$\begin{array}{l}\text { Cuttings } \\
\text { (Branch) }\end{array}$} & \multicolumn{5}{|c|}{ Application of IBA and NAA (ppm) } & \multirow[b]{2}{*}{ Mean } \\
\hline & $\begin{array}{c}\mathbf{K}_{\mathbf{0}} \\
(0+0)\end{array}$ & $\begin{array}{c}\mathbf{K}_{\mathbf{1}} \\
(2500+0)\end{array}$ & $\begin{array}{c}\mathbf{K}_{\mathbf{2}} \\
(0+2500)\end{array}$ & $\begin{array}{c}\mathbf{K}_{\mathbf{3}} \\
(1500+ \\
1000)\end{array}$ & $\begin{array}{c}\mathbf{K}_{\mathbf{4}} \\
(1000+ \\
1500) \\
\end{array}$ & \\
\hline & \multicolumn{6}{|c|}{.$\% \ldots \ldots \ldots \ldots$} \\
\hline $\mathrm{B}_{1}$ (Primary) & $11.10 \mathrm{c}$ & $55.57 \mathrm{a}$ & $22.20 \mathrm{bc}$ & $55.57 \mathrm{ab}$ & $11.10 \mathrm{c}$ & 31.11 \\
\hline $\mathrm{B}_{2}$ (Secondary) & $33.33 \mathrm{abc}$ & $11.10 \mathrm{c}$ & $22.20 \mathrm{bc}$ & $0.00 \mathrm{c}$ & $22.20 \mathrm{bc}$ & 17.77 \\
\hline Mean & 22.22 & 33.33 & 22.20 & 27.78 & 16.65 & \\
\hline
\end{tabular}

Notes: The numbers followed by similar letters in the same row show no significant difference in Duncan Multiple Range Test at $\alpha=5 \%$.

Table 3 shows that using primary branch produces the highest percentage of rooted cuttings $(55.57 \%)$ in the administration of IBA $2500 \mathrm{ppm}+$ NAA $0 \mathrm{ppm}\left(\mathrm{K}_{1}\right)$ which is not significantly different from $\mathrm{K}_{3}$ but is significantly different from $\mathrm{K}_{0}, \mathrm{~K}_{2}$ and $\mathrm{K}_{4}$. Using secondary branch produces the highest percentage of rooted cuttings $(33.33 \%)$ in the administration of IBA $0+$ NAA 0 ppm $\left(K_{0}\right)$ which is not significantly different from $K_{1}, K_{2}, K_{3}$ and $K_{4}$.

In the primary branch cuttings, the highest percentage of rooted cuttings found in the administration of IBA $2500 \mathrm{ppm}+$ NAA $0 \mathrm{ppm}$. This happens because the primary branch is older and has more carbohydrate content with a relatively low non meristematic endogenous auxin, thus administering exogenous auxin will encourage the formation of roots where IBA is a more stable hormone to stimulate rooting. This is in line with Sulastri [12] statement arguing that Indole Butyric Acid (IBA), in addition to its long-lasting effect, has more stable chemical properties and mobility in plants. Such qualities make IBA more successful. This ZPT stays near the application point and does not spread to other cuttings so it does not affect the growth of other parts. Meanwhile, the secondary branch has a sufficient endogenous auxin thus without the administration of exogenous auxin, it can stimulate the root growth.

\subsection{The Number of Shoots}

The percentage of shoots on the treatment of administering IBA and NAA can be seen in Table 4. The finding presented in Table 4 shows that the primary branch cuttings have more number of shoots ( 0.82 buds) which are not significantly different from the secondary branch cuttings. In the treatment of IBA and NAA, the largest number of shoots ( 0.89 buds) is obtained from the administration of IBA $2500 \mathrm{ppm}+$ NAA $0 \mathrm{ppm}\left(\mathrm{K}_{1}\right)$ which is not significantly different from $\mathrm{K}_{0}, \mathrm{~K}_{2}, \mathrm{~K}_{3}$ and $\mathrm{K}_{4}$. 
Table 4. Number of Shoots on the Treatment of Administering IBA and NAA After 15 Weeks of Planting

\begin{tabular}{ccccccc}
\hline & \multicolumn{5}{c}{ Application of IBA and NAA (ppm) } \\
\cline { 2 - 6 } Cuttings & $\mathbf{K}_{\mathbf{0}}$ & $\mathbf{K}_{\mathbf{1}}$ & $\mathbf{K}_{\mathbf{2}}$ & $\mathbf{K}_{\mathbf{3}}$ & $\mathbf{K}_{\mathbf{4}}$ & \multirow{2}{*}{ Mean } \\
& $(0+0)$ & $(2500+$ & $(0+$ & $(1500+$ & $(1000+$ & \\
\hline & $0)$ & $2500)$ & $1000)$ & $1500)$ & \\
B1 (Primary) & 0.56 & 1.22 & 1.00 & 0.89 & 0.44 & $0.82 \mathrm{a}$ \\
B2 (Secondary) & 0.78 & 0.56 & 0.67 & 0.44 & 0.56 & $0.60 \mathrm{~b}$ \\
\hline Mean & 0.67 & 0.89 & 0.83 & 0.67 & 0.50 & \\
\hline
\end{tabular}

Notes: The numbers followed by similar letters no significant difference in Duncan Multiple Range Test at $\alpha=5 \%$.

The highest number of shoots was obtained from the primary branch cuttings $\left(\mathrm{B}_{1}\right)$ presumably due to the larger amount of available nutrients than in the secondary branch cuttings. The availability of nutrient provides sufficient energy for plants to develop, enlarge and elongate the cell which then affects the growth of better plant organs. This is in line with Hartmann et al. [11] stating that the success rate of cuttings in producing shoots is caused by the content of nutrient possessed by the cuttings for growth and development.

\subsection{Shoot Length}

The percentage of shoot length on the treatment of administering IBA and NAA can be seen in Table 5. Table 5 shows that using primary branch cuttings produces the highest shoot length $(2.70 \mathrm{~cm})$ with the administration of IBA $1500 \mathrm{ppm}+\mathrm{NAA} 1000 \mathrm{ppm}\left(\mathrm{K}_{3}\right)$ which is not significantly different from $\mathrm{K}_{1}$ but is significantly different from $\mathrm{K}_{0}, \mathrm{~K}_{2}$ and $\mathrm{K}_{4}$. In secondary branch cuttings, the highest shoot length $(1.66 \mathrm{~cm})$ is obtained from the administration of IBA 0 $\mathrm{ppm}+\mathrm{NAA} 0 \mathrm{ppm}\left(\mathrm{K}_{0}\right)$ which is not significantly different from $\mathrm{K}_{1}, \mathrm{~K}_{2}, \mathrm{~K}_{3}$ and $\mathrm{K}_{4}$.

Table 5. Shoot Length of Cuttings on the Treatment of Administering IBA and NAA after 15 Weeks of Planting

\begin{tabular}{|c|c|c|c|c|c|c|}
\hline \multirow[b]{2}{*}{ Cuttings } & \multicolumn{5}{|c|}{ Application of IBA and NAA (ppm) } & \multirow[b]{2}{*}{ Mean } \\
\hline & $\begin{array}{c}\mathbf{K}_{\mathbf{0}} \\
(0+0)\end{array}$ & $\begin{array}{c}\mathbf{K}_{\mathbf{1}} \\
(2500+0)\end{array}$ & $\begin{array}{c}\mathbf{K}_{\mathbf{2}} \\
(0+2500)\end{array}$ & $\begin{array}{c}\mathbf{K}_{\mathbf{3}} \\
(1500+ \\
1000)\end{array}$ & $\begin{array}{c}\mathbf{K}_{\mathbf{4}} \\
(1000+ \\
1500)\end{array}$ & \\
\hline & & & & & & \\
\hline B1 (Primary) & $0.94 b c$ & $1.87 \mathrm{ab}$ & $1.06 \mathrm{bc}$ & $2.70 \mathrm{a}$ & $0.58 \mathrm{c}$ & 1.43 \\
\hline B2 (Secondary) & $1.66 \mathrm{abc}$ & $0.96 \mathrm{bc}$ & $0.69 \mathrm{bc}$ & $0.46 \mathrm{c}$ & $1.46 \mathrm{bc}$ & 1.04 \\
\hline Mean & 1.30 & 1.41 & 0.88 & 1.58 & 1.02 & \\
\hline
\end{tabular}

Notes: The numbers followed by similar letters show no significant difference in Duncan Multiple Range Test at $\alpha=5 \%$.

The interaction between the cuttings and the administration of IBA and NAA growth regulators has a significant effect on the shoot length where the longest shoot was obtained from the primary branch cuttings $\left(\mathrm{B}_{1}\right)$ administered with IBA $1500 \mathrm{ppm}+\mathrm{NAA} 1000 \mathrm{ppm}\left(\mathrm{K}_{3}\right)$. Using primary fruit branch cutting results in a better growth since it has a higher carbohydrate content 
than the secondary fruit branch. Moreover, it is older than the secondary branch, so it has sufficient nutrient resource until the shoots and roots are formed. This is in line with Fauza et al. [13] stating that cuttings derived from slightly woody or woody tissues survive longer because they have higher nutrient content than those derived from soft tissues. In addition, administering a combination of IBA and NAA growth regulators as exogenous auxin will promote the formation of roots and shoots, and combined auxin will give better results than administering them separately. After being applied, IBA will remain in the application area, while NAA will be translocated throughout the body of the plant so it will stimulate the shoot to grow. This finding supports the statement of Hartmann et al. [11] arguing that using IBA and NAA combination with equal comparison is more effective than using them separately.

\subsection{Root Volume}

The percentage of rooted cuttings on the treatment of administering IBA and NAA can be seen in Table 6.

Table 6. Root Volume on Application of IBA and NAA after 15 Weeks of Planting

\begin{tabular}{|c|c|c|c|c|c|c|}
\hline \multirow[b]{2}{*}{$\begin{array}{l}\text { Cuttings } \\
\text { (Branch) }\end{array}$} & \multicolumn{5}{|c|}{ Application of IBA and NAA (ppm) } & \multirow[b]{2}{*}{ Mean } \\
\hline & $\begin{array}{c}\mathbf{K}_{\mathbf{0}} \\
(0+0)\end{array}$ & $\begin{array}{c}\mathbf{K}_{\mathbf{1}} \\
(2500+0)\end{array}$ & $\begin{array}{c}\mathbf{K}_{\mathbf{2}} \\
(0+2500)\end{array}$ & $\begin{array}{c}\mathbf{K}_{\mathbf{3}} \\
(1500+1000)\end{array}$ & $\begin{array}{c}\mathbf{K}_{\mathbf{4}} \\
(1000+1500)\end{array}$ & \\
\hline & & & &.. $\mathrm{ml} \ldots$ & & \\
\hline $\mathrm{B}_{1}$ (Primary) & $0.11 \mathrm{~cd}$ & $0.89 \mathrm{a}$ & $0.39 \mathrm{~cd}$ & $0.83 \mathrm{ab}$ & $0.06 \mathrm{~cd}$ & 0.46 \\
\hline $\mathrm{B}_{2}$ (Secondary) & $0.44 \mathrm{bc}$ & $0.01 \mathrm{~cd}$ & $0.04 \mathrm{~cd}$ & $0.00 \mathrm{~d}$ & $0.24 \mathrm{~cd}$ & 0.15 \\
\hline Mean & 0.28 & 045 & 0.22 & 0.42 & 0.15 & \\
\hline
\end{tabular}

Notes: The numbers followed by similar letters show no significant difference in Duncan Multiple Range Test at $\alpha=5 \%$.

Table 6 shows that using the primary branch cuttings produces the highest root volume $(0.89 \mathrm{~g})$ with the administration of IBA $2500 \mathrm{ppm}+$ NAA $0 \mathrm{ppm}\left(\mathrm{K}_{1}\right)$ which is not significantly different from $\mathrm{K}_{3}$ but significantly different from $\mathrm{K}_{0}, \mathrm{~K}_{2}$ and $\mathrm{K}_{4}$. In using secondary branch cuttings, the highest root volume $(0.44 \mathrm{~g})$ is obtained from the administration of IBA $0 \mathrm{ppm}+$ NAA $0 \mathrm{ppm}$ $\left(\mathrm{K}_{0}\right)$ which is not significantly different from $\mathrm{K}_{1}, \mathrm{~K}_{2}$ and $\mathrm{K}_{4}$ but significantly different from $\mathrm{K}_{3}$. The high root volume on the primary branch cuttings with the administration of IBA $2500 \mathrm{ppm}$ + NAA 0 ppm is equal to the percentage of higher rooted cuttings because the primary branch has higher carbohydrate content that can be used as nutrients. Although the endogenous auxin in the primary branch is less than in the secondary branch, exogenous auxin administration helps the process of root formation. IBA is a more stable auxin and is not translocated to all other parts of the plant so that it remains in the area of application. This is in line with Sulastri [12] statement arguing that Indole Butyric Acid (IBA), in addition to its long-lasting effect, has more stable chemical properties and mobility in plants. Such qualities make IBA more successful. This ZPT stays near the application point and does not spread to other cuttings thus it does not affect the growth of other parts. 


\section{Conclusion}

The higher emerging shoot rate is found on the secondary branch cuttings, while the highest number of shoots and root volume is found on the primary branch cuttings. The application of IBA and NAA has no significant effect on the growth of pepper cuttings. The highest shoot length was found on the primary branch cuttings through the administration of IBA $1500 \mathrm{ppm}+$ NAA $1000 \mathrm{ppm}$, and the highest percentage of rooted cuttings and root volume are found on the primary branch cuttings through the administration of IBA $2500 \mathrm{ppm}+$ NAA 0 ppm.

\section{REFERENCES}

[1] A.O. Siregar, Pertumbuhan bibit lada perdu pada komposisi media tanam berbeda dengan penyungkupan. Bengkulu: Universitas Bengkulu, 2013.

[2] Indonesia Directorate General of Plantation, Statistik perkebunan indonesia "lada". Jakarta: Kementerian Pertanian, 2015.

[3] D. Manohara and d. Wahyuno, Pedoman budidaya merica. Bogor: World Agroforestry Centre Southeast Asia Regional Program, 2013.

[4] M. P. Yufdi and Y. Pujiharti, "Kemungkinan pengembangan lada dengan setek cabang buah," Prosiding Simposium Hasil Penelitian dan Pengembangan Tanaman Industri, 1989.

[5] I. Hariyadi, Darmawan, and R. Zaubin, "Pengaruh jenis setek dan media pembibitan terhadap pertumbuhan bibit tanaman lada (Piper nigrum L.)," Bul. Agro, vol. 24, no. 1, pp. 6-9, 1996.

[6] S. Kusumo, Zat pengatur tumbuh tanaman. Jakarta: CV Yasaguna, 1984.

[7] D. Maulida, Rugayah, and D. Andalasari, "Pengaruh pemberian IBA (Indole Butyric Acid) dan konsentrasi NAA (Naphthalene Acetic Acid) terhadap keberhasilan penyetekan sirih merah (Piper crocatum Ruiz and Pav.)," Jurnal Penelitian Pertanian Terapan, vol. 13 no. 13, pp. 151-158, 2013.

[8] E. Nilasari, "Pengaruh konsentrasi IBA (Indole Butyric Acid) terhadap pertumbuhan bibit cabe jawa (Piper retrofactum Vahl.) dari tiga daerah produksi," Thesis, Universitas Jember, Jember. 2015.

[9] K. A. Gomez and A. A. Gomez, Prosedur Statistik untuk Penelitian Pertanian, Edisi kedua. Jakarta: UI Press, 1995.

[10] Z. I. Fahmi, Kajian Pengaruh Auksin terhadap Perkecambahan Benih dan Pertumbuhan Tanaman. Surabaya: Balai Besar Perbenihan dan Proteksi Tanaman Perkebunan Surabaya, 2014.

[11] H. T. Hartmann et al., Plant Propagation: Principles and Practices, $6^{\text {th }}$ Edition. New Delhi: Prentice Hall of India Private Limited, 2002.

[12] Y. S. Sulastri, "Pengaruh konsentrasi Indole Butyric Acid (IBA) dan lama perendaman terhadap pertumbuhan setek pucuk jambu air (Syzygium semarangense Burn. F. Alst)," Jurnal Pertanian, vol. 2, no. 3, pp. 25-34, 2004.

[13] H. Fauza, E. Syofyanti and I. Ferita, "Pengaruh jaringan yang digunakan sebagai bahan setek terhadap pertumbuhan beberapa tipe tanaman gambir," Thesis, Faculty of Agriculture Universitas Andalas, Padang, 2006. 